\title{
HOW TO AVOID HUMAN-ANIMAL DICHOTOMY AND BECOME ETHICAL
}

\author{
Gunja Kathet
}

\begin{abstract}
Anthropomorphizing is not simply lending human attributes to nonhuman animals; but in the very act of lending, there is taming and domesticating of animals. This paper in the light of Critical Animal Studies (CAS) argues that the companion/ pet species are the result of human intervention in the wilderness, taking away the natural life of cats, dogs, horses, and so many others; then, caging or leashing them, thus suspending their rights, even while proliferating their population. While feeding them "properly, " proper to human standards, humans have weakened the pet species' immunity and aggravated their vulnerability. Since it is, at the end, for the pleasure and wellbeing of human, anthropomorphism is also anthropocentrism.
\end{abstract}

Keywords: Anthropocentrism, Post-Humanism, Proliferation, Dichotomy

The humanist concept of world-forming argues that human must come to an end before we can reconfigure the question of animal without surrendering to anthropocentrism or anthropomorphism. Even the most innocent idea of pet keeping slides into anthropocentrism. The question is how to avoid such traps. Neither can we subscribe to humanist divide between the human and the animal on the basis of capacities nor can we claim that we are being ethical to pet animals by feeding them "our" food or giving them shelter. Anthropomorphizing is not simply lending human attributes to nonhuman animals; but in the very act of lending, there is taming and domesticating of animals. The companion/ pet species are the result of and due to human intervention in the wilderness, taking away the natural life of cats, dogs, horses, and so many others; then, caging or leashing them, thus suspending their rights, even while proliferating their population. While feeding them "properly," proper to human standards, humans have weakened the pet species' immunity and aggravated their vulnerability. Since it is, at the end, for the pleasure and wellbeing of human, anthropomorphism is also anthropocentrism. Let us define both anthropocentrism and anthropomorphism and then see where Heidegger's world-forming man falls. In order to do so, I would like to reiterate Weitzenfield and Joy's overview on anthropocentrism. They argue that anthropomorphism is narcissistic in its origin and is a form of distorted humanism. For Heidegger, man will only find himself through entry into the meaning of Being, which involves detachment (gelassenheit), i.e. by letting Being be:

...Anthropocentrism, which has narcissistically privileged humans as the center of all significance, is not an innate disposition, but the historical outcome of a distorted humanism in which human freedom is founded upon the unfreedom of human and animal others. Nonetheless, the humanist aspiration to ground knowledge in reason

* Lecturer of English, Dillibazar Kanya Multiple Campus, TU, Nepal 
through modern science has undermined the tenability of a human-animal binary and hierarchy, thus resulting in a critique of speciesist beliefs and institutions. (1)

This remnant of anthropomorphic thinking triggers us to think that in the guise of humanist thinking we misunderstand that we have an upper hand over animals and we are able to legitimize killing animals. This is what Heidegger meant by world-forming man in his seminal essay "Animal is Poor in the world":

Man is not merely a part of the world but is also master and servant of the world in the sense of "having' world. Man has world. But then what about the other beings which, like man, are also part of the world: the animals and plants, the material things like the stone, for example? Are they merely parts of the world, as distinct from man who in addition has world? (qtd. in Calarco 17)

The cardinal questions that Heidegger posits are itself the example of how humans feel that they are answerable to every phenomena of the world. This is hubristic and self-love in the expense of other beings in the world. Heidegger further posits that "Mortals are they who can experience death as death. Animals cannot do so. But animals cannot speak either. The essential relation between death and language flashes up before us, but remains still unthought" (Calarco 18). This further gears his understanding that animals doesn't even exist because they "...cannot die in the sense in which dying is ascribed to human beings but can only come to an end" (Calarco18) Heidegger offers the following oft cited statement concerning the animal's relation to world in the context of a reflection on language and the animal's environment:

Because plants and animals are lodged in their respective environments but are never placed freely into the clearing of being which alone is "world," they lack language. But in being denied language, they are not thereby suspended wordlessly in their environment. Still, in this word "environment" converges all that is puzzling about living creatures. (Calarco 19-20)

Humanist concept of world-forming human must come to an end before we can reconfigure the question of animal without surrendering to anthropocentrism or anthropomorphism. Even the most innocent idea of pet keeping slides into anthropocentrism. The question is how to avoid such traps. Neither can we subscribe to humanist divide between the human and the animal on the basis of capacities nor can we claim that we are being ethical to pet animals by feeding them "our" food or giving them shelter. We must be ethically respectful to animals rather than dominating them in the mask of anthropomorphism.

Let us see what it is to be radically ethical with respect to animals. Homo sapiens, the species that human beings belong to, are the ones to gain most from this formulation as it gives human beings all the authority or (forges an omnipotent license) to reign over the world and its creatures. It accumulates more power, from what others supposedly lack. Dasein or being there in the world and configuring it, or its predecessor human subject, is exclusive to human beings. Non-human animals are most to loose. Animals in Heidegger are always figured as lacking namely poor in world, without language, without history, without hands (tools, including language) without dwelling, without space. The world-poor nature of the animal is important, as poverty is defined as not being what we could have. The animal cannot apprehend something as such. The animal is separated from the human being by an "Abgrund," or ontological/ existential difference. 
Compared to the stone, which has no world, "animal being is not a deprivation of world" and that "poor in world implies poverty as opposed to richness; poverty implies less as opposed to more." What this means is human being is animal plus something; animal is simply animal and less than human. If human being already has more, why would it need to turn non-human animals into poor, or deprive the already deprived? Is it not counterintuitive or outright nonsensical to make the poor poorer and claim superiority further?

If the essence of Da-sein (literally, being-there) is " being as such," and the essence of "being as such" is "to let the being be," then the essence of essence is inessence (to be something other than what it is). If that is the case, "being as such" as "let the being be" cannot be reduced to man. It applies to every living thing in that being is other than what it is (to be other than what it is means not merely being in the world but also being over the world, i.e. world-forming. There is no pure and simple "as such." Now, as for the question of relation to the world as such, the world was, is, and will remain as such whether there are living things or not or whether they relate to it or not. The world as such is the constant, regardless whether any living thing is there or not. The "as such" of the world is outside the access of every living being. Every observation of the world as such is nothing more than a perspective-making project. How does one relate to the world? One can do so only by being in the world. Every fantasy of "over the world" comes from within the world. There cannot be departure from the world to form a species-specific world. The question of what-is is a question of how one relates to it. This would require redefining life beyond every notions of essence, beyond having and not having "as such."

Let us analyze some ideas of utilitarianism and compare them with pet keeping. One can reasonably ask if this is the limit of humanism and utilitarianism as well as of today's animal rights activism. Plutarch's position could be safely characterized as indirect or involuntary anthropocentrism, which is close to Kantian utilitarianism: His position unwittingly puts human at the center after a detour that refrains from abusing, killing, and hurting non-human animals but for the ultimate benefit of the human species, in the last instance. It misses the test or mark of securing unconditional justice to other species without calculating/ rationalizing human gains:

Plutarch's attributions of intelligence, emotion, and virtue to animals converge on his statement in On the Eating of Flesh that animals 'are entitled by birth and being" to the enjoyment and duration of life'... This interpretation brings into focus the crux of Plutarch's arguments against meat eating in On the Eating of Flesh. He offers the indirect duty argument, familiar from the Epic and pre-Socratic thinkers that meat eating encourages the desire for war, and he further associates the practice with sexual lust and cruelty toward our fellow human beings. But at a more fundamental level, Plutarch suggests, the problem with meat eating is that it is unjust toward animals, as Pythagoras and Empedocles argue. (Steiner 102)

Steiner further writes that like many contemporary ethologists, Plutarch (AD 46-after 119) considers it obvious that many animals demonstrate a sense of "purpose and preparation and memory and emotions and care for their young and gratitude for benefits and hostility to what has hurt them." To this list Plutarch adds the somewhat more controversial capacities for "courage and sociability and continence and magnanimity." The evident purposiveness of animals such as bulls, wild boars, elephants, and lions is clear evidence of animal intelligence. Plutarch cites as an example of purposiveness and sociability in lions the efforts made by younger lions to alleviate 
the burden on the older lions in the pride while on the hunt. Animals show "cleverness in attacking and catching prey," for example, some fish catch others by extending a tentacle, and the octopus sometimes changes color to lure its prey.

Animals have hitherto been regarded with little ethical significance in Western philosophy and at worst they have been taken to have no ethical significance. Aristotle took animals to exist for our sake as resources. St. Paul argued that even God do not care for oxen. Christian thinkers such as Augustine and Aquinas thought that cruelty to animals was not in and of itself problematic, being problematic only as a possible source of human to human cruelty. Descartes denied that animals can in fact suffer and Kant restricted the kingdom of ends to humans, animals being mere means to our ends.

There were a few contrary voices like Montaigne who was unhappy with human arrogance and saw fit to challenge it. David Hume argued for the 'gentle usage' of animals and the British Utilitarian thinkers factored in animal suffering to their accounts of utility. Aristotle formulated a hierarchy of souls in which humans possessed an intellective soul, above the lesser degrees of souls of animals, with a sensitive soul, and plants, with a vegetative soul. Aristotle implies that this hierarchy is value-laden and not merely descriptive.

Nevertheless, such dissenting voices are in the minority and a general anthropocentrism has prevailed in the history of philosophy hitherto. Martin Heidegger's work challenges such ideas and principle of western philosophy, which actually aligns with creating pathos towards animal cause. Heidegger in "The Fundamental Concepts of Metaphysics" implies that World, Solitude, Finitude, provides an elaborate justification for such a conclusion by relying upon a set of ontological categories to distinguish animals from human beings.

Montaigne stops conspicuously short of advocating equality and full reciprocity between human beings and animals, and argues instead that he "[does] not put much stock" in "that cousinship between us and the animals." We do have "a general duty of humanity that attaches us not only to animals, who have life and feeling, but even to trees and plants." Our duty, however, is one not of reciprocal justice, but simply one of benevolence, as for Plutarch in his Life of Cato the Elder. "We owe justice to men, and mercy and kindness to other creatures that may be capable of receiving it. There is some relationship between them and us, and some mutual obligation," (Steiner 137) but not so much that animals deserve to be accorded the rights due to a full-ledged (human) member of society. One can reasonably ask if this is the limit of humanism and utilitarianism as well as of today's animal rights activism. Plutarch's position could be safely characterized as indirect or involuntary anthropocentrism, which is close to Kantian utilitarianism:

His position unwittingly puts human at the center after a detour that refrains from abusing, killing, and hurting non-human animals but for the ultimate benefit of the human species, in the last instance. It misses the test or mark of securing unconditional justice to other species without calculating/ rationalizing human gains. So, both Kantian utilitarianism and Heideggerian post-metaphysical ontology are far from being ethical. In fact, they both reintroduce anthropocentrism. (138)

Serpell's points out that considered from a moral standpoint, anthropomorphism sometimes seems dangerously allied to anthropocentrism because humans project their own thoughts and feelings onto other animal species because they egotistically believe themselves to be the center of the 
universe. From time immemorial, human beings have been attributing human emotions, human characteristics, and even human vices to animals. Cuteness is an idea of self-projection. It is not there. It is within human beings. In popular movies and epics parallel cast of animals to try out alternative plots and personalities. The monkeys who echo but also alter the human configurations of lovers, rivals, allies, and enemies in the Ramayana epic act as a kind of narrative thought experiment. Cuteness is a detour to Narcissism, self-loving under the pretext of loving the other. So, if one finds an animal cute, it may or may not be cute among my species members. One finds something cute because one projects ones idea of cuteness on their mind. That is anthropomorphism, and animal breeders emasculate and de-immunize pet animals. Indeed, an anthropomorphic characterization is never needed for a complete understanding of the behavior of a nonhuman species. Not that zoologists want to take the fun out of our viewing and reacting to animals in our peculiarly human and subjective ways. There is nothing wrong with the average zoo visitor's describing an animal as cute, endearing, or ugly. These are merely personal impressions. We may forget, too, that all animals are worthy of our attention and respect, not only those that appeal to us personally. Serpel argues, it would be tragic if we allowed some species to become extinct simply because we subjectively find them undistinguished or ungainly. The literal application of anthropomorphic attitudes would be active attempts to exterminate certain species whose appearance is unappealing to humans. This has happened in the past and continues to happen, although such animals usually also have a mistaken reputation as pests. The groundless fear many people have of all snakes, lizards, or bats illustrates such irrational and dangerous emotions. However, our aesthetic responses are perfectly natural, and scientists share them. Indeed, many have been drawn to study nature through their appreciation of natural beauty. But they have learned to appreciate the beauty of its system and of its laws. From that point of view, even grotesque and commonplace animals are beautiful. The problem may be that overemphasizing the appealing or unappealing aspects of animals may detract from our appreciating serious study and description. There is something in our attraction to an animal. In the dog, what we like is perhaps his child-like character. As if he were strong, cheerful, powerful, full of life. On the other hand, there is also, even with regards to an animal, a pity. A dog is like a wolf that doesn't bite. There is the trace of the wolf in the dog. In any case, there is here the possibility of a specific phenomenological analysis. Children are often loved for their animality. The child is not suspicious of anything. He jumps, he walks, he runs, he bites. It's delightful. There is a multiple layers of cruelty involved in pet business and pet keeping. We often mistake animals for people while reading myths, and the reverse, in sexual (or quasi-sexual)situations. They also imply that people become animals, and therefore in a sense unrecognizable, in the sexual act that Shakespeare's Iago imagined as a beast with two backs. And finally, they imply that hunting, like sex, is a vice of lust; the Arthasastra, the ancient Indian textbook of political science, lists hunting (along with sex, gambling, and drinking) under the vices of desire, and we have seen Rama, defending himself against charges of foul play against an animal, argue that even sages go hunting. The ultimate result of this conflation is that human hunters often mistake other humans for animals, particularly when they are making a mistake that has fatal consequences not only for the animals but for the unlucky hunter.

Some of the rhetorical and thought provoking questions posed by Serpel can arguably be a new perspective on Human- Pet Relationship. What happens to animal sexuality in breeding industry or pet ownership? Most die sexlessly. Male pet animal may engage occasionally in dry-humping a couch or tree trunk, but a female pet animal is entirely deprived of that. Now, what about their 
nudity, in both literal and philosophical sense? Do pet animals have a face that interrupts or shakes the foundation of human existence? In other words, when some pet animals are adorned in clothing (t-shirts, capes, jackets, hats, etc.) and when they are given human food, what happens is their face and nudity are further trampled, disfigured, therefore possibility of ethical relation is further distanced. Therefore Serpell posits Darwin's saying as an anecdote to prove his point through that human-pet relationship is unethical: "One of the most remarkable features of our domesticated races is that we see in them adaptation, not indeed to the animal's or plant's own good, but to man's use or fancy" (Serpell 121). The transformation that takes place in pet animals is a cover for human to disavow their ethical responsibility.

\section{Works Cited}

Callarco, Mattew. Heidegger's Zoontology. Eds Calarco and Atterton. Animal Philosophy: Essential Readings in Continental Thought. Continuum, 2004.

Serpell, James. People in Disguise: Anthropomorpism and the Human-Pet Relationship. Eds Daston and Mitman: Thinking with Animals: New Perspective on Anthropomorphism. Columbia University Press, 2005.

Steiner, Gary. Anthropocentrism and Its Discontents: The Moral Status of Animals in the History of Western Philosophy. Pittsburgh, Pa: University of Pittsburgh Press, 2005.

Weitzenfeld, A \& Joy, M. An overview of anthropocentrism, humanism, and speciesism in critical animal theory. New York, NY: Peter Lang Publishing. 2014. 